\title{
Exopolysaccharide biosynthesis and biodegradation by a marine hydrothermal Alteromonas sp. Strain
}

\author{
Lelchat Florian ${ }^{1,2}$, Cozien Joelle ${ }^{1,2}$, Le Costaouec Tinaig ${ }^{3}$, Brandily Christophe ${ }^{1,2}$, Schmitt Sophie $^{1,2}$, \\ Baudoux Anne-Claire ${ }^{4}$, Colliec-Jouault Sylvia ${ }^{1,2}$, Boisset Claire ${ }^{1,2,3}$
}

1 IFREMER, Technopole Brest Iroise, 29280 Plouzané, France

2 IFREMER, Rue de l'lle d'Yeu, 44311 Nantes cedex 3, France

${ }^{3}$ CERMAV, 601 rue de la Chimie, 38049 Grenoble cedex 9, France

${ }^{4}$ Station Biologique de Roscoff, CNRS, 29680 Roscoff, France

Email adresses : florian.lelchat@gmail.com ; joelle.cozien@ifremer.fr ;

tinaig.lecostaouec@cermav.cnrs.fr ; christophe.brandily@ifremer.fr ; sophie.schmitt@ifremer.fr ; anne-claire.baudoux@sb-roscoff.fr ; sylvia.colliec.jouault@ifremer.fr ; claire.boisset-helbert@cermav.cnrs.fr

\begin{abstract}
:
Alteromonas macleodii subsp. fijiensis biovar deepsane is a deep-sea ecotype exopolysaccharideproducing bacteria isolated from the polychaete annelid Alvinella pompejana. The high molecular weight biopolymer HYD657 produced by this strain, is the first marine exopolysaccharide (EPS) to be commercialized for cosmetic use. Depolymerization methods are necessary to elucidate the complete structure of this EPS and to generate potentially bioactive oligosaccharides. Enzymatic methods are useful for elucidating polysaccharide structure because they specifically cleave glycosidic bonds and do not require harsh chemical conditions. The HYD657 EPS is structurally complex and no commercially available enzymes are able to effectively degrade it. Here, we present the first results on the endogenous enzymatic depolymerization of a marine EPS of biotechnological interest by the producing strain. Enzymatic activity was detected in the bacterial lysate and was able to decrease the apparent molecular size of the EPS, releasing mainly oligosaccharides. The reduced form of the native polysaccharide showed a slightly modified osidic composition, particularly in terms of molar ratio. Several exoglycosidase activities were measured in the bacterial lysate using paranitrophenyl-osides
\end{abstract}

Keywords: Marine Alteromonas macleodii sp. strain, Bacterial exopolysaccharides, Microbial extracellular enzymes, Endogenous enzymatic degradation 


\section{Introduction}

Many bacterial strains have been found to produce exopolysaccharides (EPSs), which have a wide range of industrial applications such as emulsification, thickening, absorption, gel formation, anticancer treatment (Kumar et al. 2007 ; Freitas et al. 2010). A few EPS have been commercially developed and are produced on a large scale: xanthan, gellan, curdlan, and succinoglucan. There is a growing interest in isolating new EPSs with novel functions, new physical and chemical properties. In this regard, the marine environment is a huge resource of unknown and uncultivated bacteria that can produce and excrete EPSs. In extreme habitats, such as hydrothermal vents or cold seeps, bacteria may produce other new, bioactive EPSs. EPSs secreted by marine strains from deep hydrothermal vents exhibit a wide range of chemical structure and biological activities (Rougeaux et al. 1999; Guezennec 2002; Colliec-Jouault 2001). Interest in polysaccharides for pharmaceutical applications has been increasing in recent years as high added value compounds (Zanchetta et al. 2003a; Okutani 1984, 1992; Colliec-Jouault 2001; Courtois et al. 2014). The molecular weight or the degree of polymerization of the polymer is one of the major keys that will influence the optimal activity for a therapeutic agent or modify the rheological properties of the polysaccharide. To decrease the molecular weight of a polysaccharide, the polysaccharide is often depolymerized using chemical hydrolysis, free radical or ultrasonic methods (Petit et al. 2007). However, although this method of hydrolysis may be efficient in decreasing the average molecular weight of a native polysaccharide, it is difficult to control, lacks specificity and may affect the structure due to the loss of substituents and osidic constituents, especially those that are branched. As an alternative process, enzymatic methods are expected to improve, among other things, the specificity of glycosidic bond cleavage, the control of the polymerization degree and the preservation of the whole structure of the polysaccharide. Bacterial EPSs of marine origin are often high molecular weight polymers, structurally complex and for most of them, commercial enzymes are ineffective at initiating hydrolysis (Rigouin et al. 2012). The presence of specific endogenous polysaccharidases or polysaccharide lyases degrading the EPS produced by the same bacteria has been described for several microbial strains (Sutherland 1995, 1999a, 1999b; Legoux et al. 1997). In some cases, the expression of these enzymes can be problematic because it degrades and thereby reduces the molecular weight as well as the final yield of the produced EPS. However, they also can be used as specific tools to obtain low molecular weight derivatives of native polysaccharides.

In this study, we report results of the investigation of specific glycosyl hydrolases or polysaccharide lyases able to degrade the HYD657 EPS, called deepsane, produced and secreted by the marine Alteromonas macleodii subsp. fijiensis biovar deepsan (CambonBonavita et al. 2002). This high molecular weight polysaccharide $\left(1.5 \times 10^{6} \mathrm{Da}\right)$ already has found applications in cosmetics and is commercially available under the name of Abyssine ${ }^{\circledR}$ (patent PCT 94907582-4) for soothing and reducing irritation of sensitive skin against chemical, mechanical and UVB aggressions (Thibodeau and Takeoka 2006). We were interested in finding a specific mode of cleavage to obtain low molecular weight derivatives of deepsane to find new applications and to elucidate the complete structure of this complex polysaccharide (Le Costaouec et al. 2012). This initial investigation explored the conditions for the production of specific polysaccharidases by this EPS-producing Alteromonas macleodii strain. 


\section{Materials and methods}

\subsection{EPS production, purification and reduction}

The strain Alteromonas macleodii subsp. fijiensis biovar deepsane (CNCM I-1285) was previously isolated from the hydrothermal vent polychaete annelid Alvinella pompejana from the East Pacific Rise system at 2600 m depth during the Hydronaut cruise in 1987 (CambonBonavita et al. 2002). The HYD657 EPS was produced as already described (Le Costaouec et al. 2012). Briefly, production was carried out at $28^{\circ} \mathrm{C}$ in a $20 \mathrm{~L}$ fermenter under agitation and aerobic conditions containing Zobell medium (30 g. $\mathrm{L}^{-1}$ sea salt, $1 \mathrm{~g} . \mathrm{L}^{-1}$ yeast extract, 5 g. $\mathrm{L}^{-1}$ peptone, $\mathrm{pH}$ 7) supplemented with a carbon source (glucose, $30 \mathrm{~g} \cdot \mathrm{L}^{-1}$ ) to induce EPS excretion. Culture medium was inoculated with a $10 \%$ suspension of cells in exponential growth phase. The $\mathrm{pH}$ was maintained at 7 by automatic addition of $\mathrm{NaOH}$. Bacterial growth was determined by measuring optical density at $600 \mathrm{~nm}$. After $48 \mathrm{~h}$ of fermentation, bacterial cells were removed from the medium by centrifugation $(14,000 \times \mathrm{g}, 40 \mathrm{~min})$. The supernatant containing the excreted EPS was filtered through a cellulose membrane $(0.7 \mu \mathrm{m})$ and then ultrafiltrated (cut-off $100 \mathrm{kDa}$ ). The recovered EPS was freeze-dried and stored at room temperature away from light and moisture.

\subsection{EPS characterization}

\subsubsection{Molecular weight}

Molecular weight of the EPS was determined by high performance size exclusion chromatography (HPSEC) using a multi angle light scattering detector (MiniDawn HELEOS, Wyatt Technology) and a refractive index detector. Elution was performed on a PL-Aquagel$\mathrm{OH}$ column (Varian, fractionation range $<10^{7} \mathrm{~g} \cdot \mathrm{mol}^{-1}$ ) with $0.1 \mathrm{M} \mathrm{NH}_{4} \mathrm{OAc}$ as the eluent. To calculate the molecular mass, the $\mathrm{dn} / \mathrm{dc}$ value used was $0.145 \mathrm{~mL} \cdot \mathrm{g}^{-1}$. The polydispersity index was calculated from the $\mathrm{Mw} / \mathrm{Mn}$ ratio.

\subsubsection{Monosaccharide analysis}

The sample (4 mg) was hydrolyzed in a $72 \% \mathrm{H}_{2} \mathrm{SO}_{4}$ solution for $1 \mathrm{~h}$ at room temperature. The sample was then diluted to obtain a final concentration of $2 \mathrm{M} \mathrm{H}_{2} \mathrm{SO}_{4}$ and the hydrolysis occurred for $6 \mathrm{~h}$ at $110^{\circ} \mathrm{C}$. After cooling, neutralization by ammonia and filtration $(0.2 \mu \mathrm{m}), 20$ $\mu \mathrm{L}$ of hydrolyzed sample were injected in a Dionex® ionic chromatography device equipped with a CarboPac PA1 column and analyzed with pulsed amperometric detection (Dionex®). Neutral monosaccharides elution was carried out isocratically with $18 \mathrm{mM} \mathrm{NaOH}$ at a flow rate of $0.7 \mathrm{~mL} \cdot \mathrm{min}^{-1}$, and the elution of uronic acids with a $\mathrm{NaOH} / \mathrm{NaOAc}(18 \mathrm{mM}$ to $1.5 \mathrm{M})$ gradient. 


\subsection{Substituents analysis}

\subsubsection{Sulfate content}

Elemental analysis was performed by the CNRS Microanalysis Facility (Gif-sur-Yvette, France). Sulfate content (sodium salt) was calculated from the sulphur analysis using the following equation: sulfate group $=3.2 \times \mathrm{S} \%$.

\subsubsection{Ionic chromatography analysis}

The organic and inorganic substituents content was determined using high performance anion exchange chromatography/conductivity detection (HPAEC/CD; GP 50 pump and ED 50 detector, Dionex®). A 2 mg. $\mathrm{mL}^{-1}$ EPS solution was hydrolyzed with $0.8 \mathrm{~N} \mathrm{HCl}$ for $3 \mathrm{~h}$ at $110^{\circ} \mathrm{C}$. The solution was then diluted with $\mathrm{H}_{2} \mathrm{O}$ and a volume of $20 \mu \mathrm{L}$ was injected. Substituents were separated on AS11HC lonpac analytical column (4x250 mm Dionex®) with a $\mathrm{NaOH}$ linear gradient from $0.15 \mathrm{mM}$ to $6 \mathrm{mM}$ as the eluent.

\subsection{EPS reduction}

Lyophilized EPS was dissolved in Milli-Q $\mathrm{H}_{2} \mathrm{O}$ at a concentration of $0.4 \%(\mathrm{w} / \mathrm{v})$ and was reduced at $4^{\circ} \mathrm{C}$ under agitation with $0.4 \%(\mathrm{w} / \mathrm{v}) \mathrm{NaBH}_{4}$ during $16 \mathrm{~h}$. Reduced EPS (EPSr) was dialyzed (cut-off, 6-8 kDa) against Milli-Q $\mathrm{H}_{2} \mathrm{O}$, lyophilized and stored at room temperature away from light and moisture.

\subsection{Production of protein extracts}

\subsubsection{Culture conditions}

The HYD657 strain was cultivated in $2 \mathrm{~L}$ flasks. EPS production can be related to the C:N ratio of the medium. Thus, three cultivation conditions were tested with different $\mathrm{C}: \mathrm{N}$ ratios.

- Zobell (Z): $30 \mathrm{~g} \cdot \mathrm{L}^{-1}$ sea salt, $1 \mathrm{~g} \cdot \mathrm{L}^{-1}$ yeast extract, $5 \mathrm{~g} \cdot \mathrm{L}^{-1}$ peptone, $\mathrm{pH} 7$ (Normal C:N ratio)

- Zobell with addition of glucose (ZG): Zobell +30 g.L ${ }^{-1}$ D-glucose, $\mathrm{pH} 7$ (High C:N ratio)

- Minimal medium (M): 30 g.L ${ }^{-1}$ sea salt, 0.3 g.L ${ }^{-1}$ yeast extract, $\mathrm{pH} 7$ (Low C, Low N)

All three media $(2 \mathrm{~L})$ were inoculated at $10 \%(\mathrm{v} / \mathrm{v})$ with a bacterial suspension in the exponential growth phase. Medium were oxygenated at an agitation rate of $150 \mathrm{rpm}$. Bacterial growth occurred at $30^{\circ} \mathrm{C}$ for $4-5$ days and was followed by measuring the culture optical density (OD) at $600 \mathrm{~nm}$.

All the steps of the preparation of protein extracts were carried out at $4^{\circ} \mathrm{C}$ to avoid the loss of potential enzyme activities. The buffer used for samples preparation was $10 \mathrm{mM}$ Tris $\mathrm{HCl}$, $0.1 \mathrm{M} \mathrm{NaCl}, \mathrm{pH} 8$. 


\subsubsection{Preparation of protein extracts from the culture supernatant}

After centrifugation of the whole culture at $14000 \mathrm{~g}$ for $40 \mathrm{~min}$, supernatant was concentrated with tangential ultrafiltration $(10 \mathrm{kDa})$ up to $50 \mathrm{~mL}$. A protease inhibitor (cOmplete EDTA-free, Roche) was added to prevent any potential proteolytic activity after cell lysis. Supernatant proteins (called Sc) were then precipitated overnight with the addition of ammonium sulfate until saturation. After centrifugation at $13,000 \times \mathrm{g}$ for $1 \mathrm{~h}$, the protein pellet (called Sp) was suspended in $15 \mathrm{~mL}$ of $10 \mathrm{mM}$ Tris $\mathrm{HCl}, 0.1 \mathrm{M} \mathrm{NaCl}, \mathrm{pH} 8$ buffer and dialyzed against the same buffer. The final protein concentration was measured using the Bradford method (1976). The Sp protein extract was stored at $-80^{\circ} \mathrm{C}$ until incubation with EPS.

\subsubsection{Preparation of protein extracts from the bacterial pellet}

After centrifugation of the whole culture at $14000 \mathrm{~g}$ for $40 \mathrm{~min}$, the pellet was washed with buffer by successive centrifugations $(10,000 \times \mathrm{g}, 15 \mathrm{~min})$ and then suspended in $40 \mathrm{~mL}$ of buffer with addition of protease inhibitor (cOmplete EDTA-free, Roche). Bacterial cell lysis was performed with a One Shot Disrupter Cell (Constant Systems ${ }^{\circledR}$ ) at a pressure of 1600 bar. For larger volumes of protein pellet, lysis was done by sonication using an ultrasonic probe (3 cycles of 20 min with 10 min effective, Bioblock ${ }^{\circledR}$ Scientific, VibraCell 72,408). Efficiency of bacterial lysis was checked by observationunder an optical microscope (Olympus Dp71®) before and after lysis. Furthermore, $200 \mu \mathrm{L}$ of DNase $\left(1 \mathrm{mg} \cdot \mathrm{mL}^{-1}\right)$ was added to eliminate bacterial nucleic acids and to reduce the risk of bacterial regrowth. The crude lysate (LD) was centrifuged at $13,000 \times \mathrm{g}$ for $1 \mathrm{~h}$ to separate the clear lysate (L) from the insoluble cell debris (D). The debris was suspended in $40 \mathrm{~mL}$ of buffer and washed by centrifugation with fresh buffer. The lysate was washed by ultrafiltration (10 kDa) and concentrated to a $20 \mathrm{~mL}$ volume. The protein extracts $L D, L$ and $D$ were stored at $-80^{\circ} \mathrm{C}$ until incubation with EPS. The protein concentration was measured by the Bradford method (1976).

\subsection{Enzyme assays}

Several incubation conditions were evaluated for each of the protein extracts to determine the most effective conditions for the degradation of native EPS and reduced EPS (EPSr). A range of temperature $\left(25^{\circ} \mathrm{C}\right.$ to $\left.45^{\circ} \mathrm{C}\right)$, incubation time $(1 \mathrm{~h}$ to 9 days) and buffers varying in composition and/or ionic strength and $\mathrm{pH}$ were tested. EPS or EPSr were diluted in buffer to a concentration of $0.4 \%(\mathrm{w} / \mathrm{v})$ with $0.04 \%(\mathrm{w} / \mathrm{v})$ of added $\mathrm{NaN}_{3}$. One volume of EPS or EPSr was incubated with one volume of the tested protein extract ( $\mathrm{Sp}, \mathrm{D}$ or $\mathrm{L}$ ), to reach a final concentration of $380 \mu \mathrm{g} \cdot \mathrm{mL}^{-1}$ total proteins and $2 \mathrm{mg} \mathrm{mL}^{-1}$ EPS or EPSr in the tested buffers. An aliquot, which was immediately frozen, corresponded to the initial incubation time $T_{0}$ and samples were taken various time steps. At the end of incubation, enzyme activity was deactivated by heating the sample to $100^{\circ} \mathrm{C}$ for $5 \mathrm{~min}$. Samples were then centrifuged for 10 min at $10,000 \times \mathrm{g}$ and the supernatant was stored at $-20^{\circ} \mathrm{C}$ until analysis.

\subsection{Detection of enzyme activities}

\subsubsection{Agarose gel electrophoresis}

The polysaccharide degradation pattern was visualized using agarose gel electrophoresis according to the method of Lee and Cowman (1994). With HYD657 being an acidic polysaccharide, runs were conducted at $\mathrm{pH}$ 8.5. Briefly, agarose gel (1\%) was prepared in Tris/acetic acid /EDTA buffer (TAE 10X : $48.4 \mathrm{~g}$ Trizma Base ; $11.42 \mathrm{~g} \mathrm{CH}_{3} \mathrm{COOH} ; 7.44 \mathrm{~g}$ 
$\mathrm{Na}_{2}$ EDTA; $\mathrm{pH}$ 8.5). Then, $12 \mu \mathrm{L}$ of the incubated sample was loaded on the gel and electrophoresis was run for $75 \mathrm{~min}$ at a voltage of $100 \mathrm{~V}$.

The gel was stained overnight in a Stains All solution (Lee and Cowman 1994; Volpi and Maccari 2002) (10 mL of 3,3'-diethyl-9-methyl-4,5,4',5'-dibenzothiacarbocyanine $0.1 \%$ in $\mathrm{N}, \mathrm{N}$-dimethylformamide, $10 \mathrm{~mL}$ of $\mathrm{N}, \mathrm{N}$-dimethylformamide; $50 \mathrm{~mL}$ of isopropanol ; $10 \mathrm{~mL}$ of $300 \mathrm{mM}$ Tris $\mathrm{HCl} \mathrm{pH} \mathrm{8.8,} \mathrm{completed} \mathrm{to} 200 \mathrm{~mL}$ with ultrapure water). The gel was then destained for $2 \mathrm{~h}$ in natural light.

\subsubsection{Para-nitrophenyl substrates}

Glycosyl hydrolase activities were measured by using $p$-nitrophenyl-oside (PNP) substrates and the amount of $p$-nitrophenol released was determined spectrophotometrically at $410 \mathrm{~nm}$ in alkaline $\mathrm{pH}$. In a 96-well microplate, the reaction mixture $(0.2 \mathrm{~mL})$ contained $100 \mu \mathrm{L} P N P$ substrate at $500 \mu \mathrm{mol} . \mathrm{mL}^{-1}$ in $10 \mathrm{mM}$ Tris $\mathrm{HCl}, 0.1 \mathrm{M} \mathrm{NaCl}, \mathrm{pH} 8$ buffer at $30^{\circ} \mathrm{C}$. The reaction was initiated with the addition of $100 \mu \mathrm{L}$ protein solution. Enzymatic kinetics were studied for $10 \mathrm{~h}$ under agitation $(100 \mathrm{rpm})$ at $30^{\circ} \mathrm{C}$. Thirteen PNP substrates were tested: paranitrophenyl- $\alpha \& \beta$-D-mannopyranoside; para-nitrophenyl- $\alpha \& \beta$-D-galactopyranoside; paranitrophenyl- $\alpha \& \beta$-D-glucopyranoside; para-nitrophenyl- $\alpha$ \& $\beta$-L-fucopyranoside; paranitrophenyl- $\alpha-L-$-rhamnopyranoside ; para-nitrophenyl- $\beta$-D-glucuronide ; para-nitrophenyl- $\alpha$ \& $\beta$-D-xylopyranoside; para-nitrophenyl- $\beta$-D-N-acetylglucosaminide.

\subsection{Size-exclusion chromatography}

After incubation with active protein fractions, samples were analyzed using size exclusion chromatography (SEC) on an Akta Fast Protein Liquid Chromatography apparatus (GE Healthcare Life Sciences $®$ ) equipped with a Superdex 200 10/300 column (GE Healthcare $200 \AA$ ). Samples were recovered after incubation, dialyzed against ultrapure water through 100 Da cut-off membranes (Biotech CE dialysis tubing, SpectraPor®), lyophilized and diluted to $1 \mathrm{mg} \cdot \mathrm{mL}^{-1}$ with ammonium acetate $(0.1 \mathrm{M})$ used as the elution buffer. Samples were then injected with a $200 \mu \mathrm{L}$ loop, separated with ammonium acetate $(0.1 \mathrm{M})$ at $0.5 \mathrm{~mL} \cdot \mathrm{min}^{-1}$ and detected using UV and refractometry to discern signals that could be assigned to proteins or polypeptides, but not sugars.

\subsection{Determination of reducing sugars using the potassium ferricyanide assay.}

The amount of reducing sugars was assayed using the Kidby and Davidson method (1979) based on the reduction of ferricyanide ions measured at $420 \mathrm{~nm}$. Briefly, $100 \mu \mathrm{L}$ of the previously ultrafiltated sample (cut-off $10 \mathrm{kDa}$, centrifugal ultrafiltration, Amicon) was mixed with $1 \mathrm{~mL}$ of reagent $\left(300 \mathrm{mg} \mathrm{K}{ }_{3}\left[\mathrm{Fe}(\mathrm{CN})_{6}\right], 23.93 \mathrm{~g} \mathrm{Na}_{2} \mathrm{CO}_{3}, 1 \mathrm{~mL}\right.$ of $5 \mathrm{M}$ sodium hydroxide; completed to $1 \mathrm{~L}$ with ultrapure water). The mixture was heated for $7 \mathrm{~min}$ at $100^{\circ} \mathrm{C}$ and then cooled on ice for $4 \mathrm{~min}$. The absorbance of the samples and standards was read at $420 \mathrm{~nm}$.

\subsection{Enzyme kinetic}

A $33 \mathrm{~h}$ enzyme kinetic was performed with lysate (L) and reduced EPS according the optimal incubation conditions determined previously (see above). Samples were taken every hour from 1 to $5 \mathrm{~h}$, every $2 \mathrm{~h}$ from 5 to $11 \mathrm{~h}$ and some other samples were taken up to $33 \mathrm{~h}$ of incubation. Protein extracts and EPSr were incubated alone in buffer to check for any potential auto-hydrolysis phenomenon. Migration patterns were compared for each sample 
on a $1 \%$ agarose gel. Agarose gel electrophoresis results were confirmed using SEC. Samples were injected though a Superdex-200 column. Chromatograms were recorded with a refractive index detector.

\subsection{Analysis of degradation products}

EPSr was incubated with the lysate $(L)$ in the reaction buffer for 3 days. This was followed by a dialysis with a cut-off of $100 \mathrm{Da}$ to remove most of the salts. Fractionation was performed using SEC (Superdex 200 column 10/300 GL). Freeze-drying eliminated most of the elution buffer salts $(0.1 \mathrm{M}$ ammonium acetate). The osidic composition of samples was analyzed by ionic chromatography (Dionex) on a carbopack PA1 column with amperometric detection.

\section{Results}

\subsection{EPS production}

The lyophilized native and reduced EPS were characterized as to their percentages of proteins and saccharides, monosaccharide ratios and substituent composition (Tables 1 and 2).

The native and reduced biopolymers were high molecular weight EPSs constituted of seven different monosaccharides, two organic substituents, i.e. lactate and pyruvate and an inorganic sulfate group. The composition was similar to that determined previously by Le Costaouec et al. (2012). Reduction of the HYD657 EPS (EPSr) was performed to eliminate all the potential reducing ends present in the lyophilized polysaccharide. The osidic composition as well as the presence of substituents did not change after reduction of the polysaccharide with $\mathrm{NaBH}_{4}$.

\subsection{Optimization of culture and incubation conditions}

Three culture media were assessed with regard to protein extract production: (1) Zobell, (2) Zobell containing glucose and (3) minimal media containing only sea salts and a low concentration of yeast extract. The resulting products of the incubations were examined on $1 \%$ agarose gels. The distance of migration of a polysaccharide within an agarose gel depends essentially on the charge and the molecular weight of the chains. No changes in the migration patterns were observed for the EPS mixed with the proteins produced and extracted from the Zobell and the minimal culture media. Both EPS and EPSr incubated with the proteins produced from the Zobell medium containing glucose were apparently hydrolyzed by LD, L and D extracts (Fig.1). Similarly, no effect was observed with the protein extracts recovered from the Sc and Sp supernatants. Active enzymes therefore appear to be produced and localized in the bacterial cells. After migration, the pattern of the native and reduced EPS in the incubation buffer showed broad, extended smear that was consistent with the disperse molecular weights previously obtained from HPSEC measurements (Table 2). The protein extracts in buffer solution showed weak bands in the gel. The native EPS incubated with the LD, D and L extracts (EPS+LD; EPS+L; EPS+D) showed low mobility for the initial band corresponding to five days of incubation. The highest molecular weight polysaccharide chains were apparently hydrolyzed. Nevertheless, the observed bands were broad and extended showing a weak hydrolysis of the native EPS by the three extracts. Depolymerization was more pronounced in the reduced form of the HYD657 EPS (EPSr) 
compared to the native form of the EPS. The initial broad extended band observed in the gel moved to a single wide spot, suggesting a drastic decrease in the molecular weight and the polydispersity of the polysaccharide chains. Regarding the assays on cell debris, the first experiment used debris that were not been washed with buffer. The observed change in migration was not observed after additional experiments on debris washed three times with fresh buffer. The LD and L protein extracts thus appear to be the best source of potentially active depolymerases. The $L$ protein extract was selected for further experiments given the higher likelihood of obtaining soluble proteins.

Native and reduced EPSs were then incubated with the $L$ protein extract obtained after cell lysis and elimination of residual cells debris. Various reaction buffers were tested with variations in $\mathrm{pH}$, salt concentration and incubation temperature. Differences in the migration patterns of EPS and EPSr were followed on 1\% agarose gel stained with "Stains all" (data not shown). Variations in the patterns observed with EPSr were always more significant than for the native EPS. The acetate buffer, $\mathrm{pH} 5$, rendered the enzymes inactive towards both types of EPS as did the temperatures of $34^{\circ} \mathrm{C}, 37^{\circ} \mathrm{C}$ and $45^{\circ} \mathrm{C}$. Ultimately, the following conditions were selected for further experiments: $10 \mathrm{mM}$ Tris $\mathrm{HCl}, 0.1 \mathrm{M} \mathrm{NaCl}$ buffer, $\mathrm{pH} 8$ with an incubation temperature of $30^{\circ} \mathrm{C}$. This buffer was selected for its lower concentration of total salts because high salt concentrations can inhibit colorimetric and chromatography analysis.

\subsection{Depolymerization of HYD657 EPS}

Depolymerization of EPSr mixed with proteins obtained from the soluble lysate (L) was monitored over increasing incubation time. Migration patterns were compared for each sample on a 1\% agarose gel (Fig. 2) At T0, EPSr appeared as a broad smear as observed in the previous incubation assays. After $1 \mathrm{~h}$ of incubation with the $\mathrm{L}$ extract, a shift in the migration pattern was observed. At $3 \mathrm{~h}$ incubation, the smear completely disappeared and a spot was clearly visible at the bottom of the gel, indicating increased mobility of the polysaccharide chains and potential depolymerization. Longer incubation times did not modify the distance of EPSr migration. To confirm the changes in molecular weight with reaction time, samples were analyzed using SEC. As shown on the chromatograms (Fig. 3), after $1 \mathrm{~h}$, the molecular weight of EPSr decreased, corresponding to a low degree of polymerization of oligosaccharides and monosaccharides. No intermediate compounds, in terms of molecular weight were observed. Enzymatic depolymerization of the EPSr was also monitored by measuring the amount of reducing sugars released during hydrolysis of glycosidic bonds, during a $33 \mathrm{~h}$ reaction (Fig. 4). After incubation, samples were first ultrafiltrated through $10 \mathrm{kDa}$ membranes to eliminate all the low molecular weight polysaccharides with a size larger than $10 \mathrm{kDa}$. The amount of reducing sugars was assayed using the Kidby and Davidson method (1973). No reducing sugars were detected in the EPSr. However, the lysate protein extract provided a background amount of reducing ends that, when subtracted from the total amount of reducing sugars, gives the actual amount of sugars resulting from enzymatic depolymerization. The amount of reducing sugar released by the cell lysate during the incubation was negligible. After $11 \mathrm{~h}, 140 \mu \mathrm{g} / \mathrm{mL}$ of reducing sugars was calculated and a final amount of $160 \mu \mathrm{g} / \mathrm{mL}$ was reached at the end of the $33 \mathrm{~h}$ incubation.

To focus on a potential "exolytic" mode of action of the depolymerizing enzymes, incubation of the lysate with 13 different paranitrophenyl-oside (PNP-oside) substrates including the saccharides that make up the HYD657 EPS, was carried out in the same buffer conditions for $10 \mathrm{~h}$ (Table 3). If paranitrophenol is released and detected during the reaction, the monosaccharide linked to the PNP may be a potential substrate for the enzyme(s) present in the lysate. Substantial amounts of paranitrophenol were measured for five PNP-oside 
substrates containing $\alpha \& \beta$-D-glucose, $\beta$-D-galactose, $\beta$-L-fucose or $\beta$-D-glucuronidase. The strongest activities were measured for $\beta$-D-glucose, $\beta$-D-galactose and $\beta$-L-fucose. None of the assays resulted in paranitrophenol amount that reached the maximum of $500 \mu \mathrm{mol} . \mathrm{mL}^{-1}$ corresponding to the total substrate available (Fig. 5).

EPSr was incubated with the lysate for 3 days in the reaction buffer and dialyzed (100 Da) before chromatography. Fractionation was performed using SEC (Superdex 200 column $10 / 300 \mathrm{GL}$ ). About $32 \%$ (w/w) of the initial injected mass was recovered in the exclusion peak fraction (upper than $100 \mathrm{kDa}$ ). Results on the osidic composition of the main peak of the depolymerized polysaccharide were expressed as ratio compared to glucose for each sample (Table 4). Most of the constitutive saccharides of the native EPSr were recovered in terms of molar ratio, in the degradation product except for fucose, galactose and mannose. Fucose was not detected and the ratios of galactose, mannose and rhamnose decreased significantly.

\section{Discussion}

The endogenous degradation of EPSs by microorganisms is rarely described in the literature. Some exceptions include EPS-producing lactic acid bacteria (Badel et al. 2009; Pham et al. 2001) and alginate and hyaluronic acid-producing bacteria (Sutherland 1999). Due to the high degree of substrate specificity, there are few commercially available enzymes that act on bacterial EPSs. To use enzymes for structural determination together with classical chemical methods, to produce low molecular weight oligosaccharides or to disrupt polysaccharidic biofilms, a promising strategy is to isolate degrading enzymes from the EPSproducing strain itself. In this study, various protein extracts were produced and tested on the HYD657 EPS. Proteins obtained from the cell lysate were found to be more effective on the reduced form than on the native EPS. The reason for this difference in enzymatic activity on EPSr remains unclear and was apparently not due to the chemical features of the EPSr, which had similar osidic composition, the same fonctional groups, similar molecular weight and polydispersity as the native form. one possible explanation is a change in EPS conformation in solution after reduction, leading to better accessibility of enzymes to polysaccharide chains and glycosidic bonds. The enzymatic activity occurred under alkaline conditions ( $\mathrm{pH} 7$ to 11 with an observed optimum at $\mathrm{pH} 8$ ) and at temperature lower than $34^{\circ} \mathrm{C}$. The depolymerization of the EPS seems to occur very quickly, i.e. after only 2 or $3 \mathrm{~h}$ of incubation with proteins from the bacterial lysate. Chromatograms obtained after enzymatic hydrolysis included peaks representing low molecular weight polysaccharide and, to a lesser degree, monosaccharides without any intermediate molecular weight species. These profiles suggest two possible mode of action: 1) if only one glycosyl hydrolase or polysaccharide lyase is involved in the depolymerization of the polysaccharide, it appears to directly release low molecular weight polysaccharide. Nevertheless, the size of the degradation products is not suitable with a classical exolytic enzyme (Stone et al. 2008); 2) if two or more enzymes are active, they may act with a synergistic mode of action leading directly to low molecular weight polysaccharides (Driskill et al. 1999a). The use of PNP substrates led to the detection of three strong exo-glycosidase activities with $\square$-galactosidase, $\square$-glucosidase and $\square$ fucosidases. The composition analysis of the low molecular weight fraction of the hydrolyzed EPSr showed that ratios of galacturonic acids and glucuronic acids were not modified unlike galactose, mannose, rhamnose and fucose which all significantly decreased. As shown in Table 3, mannosidase and rhamnosidase activities were not detected with PNP-oside substrates. The exo- $\beta$-D-galactosidase activity measured with PNP substrates increased quite rapidly and to reached a plateau, whereas more than half of the substrate pool was still available. This result may be associated with the low galactose rate measured in degradation products compared to native or resistant EPS fractions. It also may highlight a probable competitive inhibition of the bacterial exo- $\beta-D$-galactosidase by the released galactose units 
(Park and Oh 2010). Exo- $\beta$-L-fucosidase activity was measured with PNP-oside, but fucose was not detected in degradation products, suggesting that this enzyme was not involved in the depolymerization process. Finally, PNP-GalA is not yet commercially available, therefore no test on potential exogalacturonidase activity was possible.

Given that the EPS-producing bacterium survives in a biofilm mainly made up of the HYD657 EPS, this type of activity has several advantages from an ecophysiological point of view. A mild depolymerization of the polysaccharide with the release of low molecular weight polysaccharides without intermediary products may have less impact on the threedimensional structure of the biofilm and thus its integrity than, for example, endoactive depolymerization. With regard to the hydrothermal origin of the strain, a sudden return of the bacteria to the planktonic state after a disruption of its biofilm may expose the strain to the deleterious factors in this type of environment (low $\mathrm{pH}$, high temperature, heavy metals). This hypothesis is moreover in agreement with the optimum conditions of the enzymatic activity observed in the study $\left(\mathrm{pH} 8,30^{\circ} \mathrm{C}\right)$. Using exolytic enzyme(s) probably also allows $A$. macleodii subsp. fijiensis to colonize new environments by releasing young cells from the top of the biofilm without destroying the entire colony. The use of the EPS as a last resort carbon source by the producing bacteria is also possible, although rarely described (Wolfaardt et al. 1999). Indeed, this type of metabolic pathway is a paradox because polymer synthesis requires a more energy than it could provide (Badel et al. 2009). Finally, the biological function of the glycosidase activity described here may be a means for the bacteria to degrade the EPS chains that fail to be exported out of the cell and thereby become stranded in the periplasm during polymer biosynthesis. This occurence has already been experimentally highlighted with Pseudomonas mutants unable to express alginate lyase and they are not viable in the presence of high amounts of alginic acid (Bakkevig et al. 2005). Moreover, our proposed mode of action is consistent with the intracellular location of the enzyme described in the present work.

This is the first description of endogenous polysaccharidases produced by a deep-ecotype strain that are active against the EPS synthesized and excreted by the same bacteria. Among the culture conditions tested, Zobell medium supplemented with glucose led to the production of hydrolytic and specific enzymes able to decrease the molecular weight of the HYD657 EPS. Several glycosyl hydrolases or polysaccharide lyases have been highlighted but the mode of action of each enzyme has still to be clarified. Purification steps will be necessary to isolate the different enzymes involved in the degradation of the HYD657 EPS of biotechnological interest produced by Alteromonas macleodii subsp. fijiensis biovar deepsane.

\section{Acknowledgments}

This research was financially supported by the French Institute for Exploitation of the Sea, the Brittany Regional Council and the GlycoOuest network for Research in Glycosciences.

\section{References}

Badel S, Bernardi T, Michaud P (2011) New perspectives for Lactobacilli exopolysaccharides. Biotechnol Adv 29:54-66.

Bakkevig K, Sletta H, Gimmestad M, Aune R, Ertesvåg H, Degnes K, Christensen BE, Ellingsen TE, Valla S ( 2005) Role of the Pseudomonas fluorescens Alginate Lyase (AlgL) in 
Clearing the Periplasm of Alginates Not Exported to the Extracellular Environment. $\mathrm{J}$ Bacteriol 187:8375-8384.

Bradford MM (1976) A rapid and sensitive method for the quantitation of microgram quantities utilizing the principle of protein dye binding. Anal Biochem 72:248-254.

Cambon-Bonavita MA, Raguenes G, Jean J, Vincent P, Guézennec J (2002) A novel polymer produced by a bacterium isolated from a deep-sea hydrothermal vent polychaete annelid. J Appl Microbiol 93(2):310-315.

Colliec-Jouault S, Chevolot L, Helley D, Ratiskol J, Bros A, Sinquin C, Roger O, Fischer AM (2001) Characterization, chemical modifications and in vitro anticoagulant properties of an exopolysaccharide produced by Alteromonas infernus, Biochem BiophysActa. 1528(23):141-151.

Courtois A, Berthou C, Guézennec J, Boisset C, Bordron A (2014) Exopolysaccharides Isolated from Hydrothermal Vent Bacteria Can Modulate the Complement System. PloS one doi 10.1371/ 0094965.

Driskill LE, Bauer MW, Kelly RM (1999a) Synergistic interactions among $\beta$-laminarinase, $\beta$ 1,4-glucanase, and $\beta$-glucosidase from the hyperthermophilic archaeon Pyrococcus furiosus during hydrolysis of $\beta-1,4-, \beta-1,3-$, and mixed-linked polysaccharides. Biotechnol and Bioeng 66:51-60.

Dubois M, Gilles KA, Hamilton JK, Rebers PA, Smith F (1956) Colorimetric method for determination of sugars and related substances. Anal Chem 28(3): 350-356.

Freitas F, Alves VD, Reis MAM, (2011) Advances in bacterial exopolysaccharides: from production to biotechnological applications. Trends in Biotechnol 29: 388-398.

Guezennec J, Cambon-Bonavita MA, Raguénès G, Jean J, Vincent P (2002) A novel polymer produced by a bacterium isolated from a deep-sea hydrothermal vent polychaete annelid. J Appl Microbiol 93(2): 310-315.

Kamerling JP, Gerwig G, Vliegenthart JF, Clamp JR (1975) Characterization by gas-liquid chromatography-mass spectrometry and proton-magnetic-resonance spectroscopy of pertrimethylsilyl methyl osidics obtained in the methanolysis of glycoproteins and glycopeptides. Biochem J 151(3): 491-495.

Kidby DK, Davidson DJA (1973) Convenient ferricyanide estimation of reducing sugars in the nanomole range. Anal Biochem 55 (1): 321-325.

Kumar AS, Mody K, Jha B, (2007) Bacterial exopolysaccharides - a perception. J of Basic Microbiol. 47:103-117.

Le Costaouëc T, Cérantola S, Ropartz D, Ratiskol J, Sinquin C, Colliec-Jouault S, Boisset C (2012) Structural data on a bacterial exopolysaccharide produced by a deep-sea Alteromonas macleodii strain. Carbohyd Pol 90: 49-59.

Lee HG, Cowman MK (1994) An agarose gel electrophoretic method for analysis of hyaluronan molecular weight distribution. Anal Biochem 219: 278-287.

Legoux R, Lelong P, Jourde C, Feuillerat C, Capdevielle J, Sure V, Ferran E, Kaghad M, Delpech B, Shire D, Ferrara P, Loison G (1997) N-Acetyl-heparosan lyase of Escherichia coli K5: Gene: Gene cloning and expression. J Bacteriol 178: 7260-7264. 
Montreuil J, Bouquelet S, Debray H, Fournet B, Spik G, Strecker G (1986) Glycoproteines. Carbohydrates analysis: a practical approach. 2nd ed. Chaplin, M. F. \& Kennedy, J. K., IRL Press, Oxford, England pp. 143-204.

Okutani K (1984) Antitumor and immunostimulant activities of polysaccharide produced by a marine bacterium of the genus Vibrio. Bull Jap Soc Sci Fish 50:145-156.

Park .R, Oh DK, (2010) Effects of galactose and glucose on the hydrolysis reaction of a thermostable $\beta$-galactosidase from Caldicellulosiruptor saccharolyticus. Appl Microbiol Biotechnol 85:1427-1435. doi:10.1007/s00253-009-2165-7.

Petit AC, Noiret N, Guezennec J, Gondrexon N, Colliec-Jouault S (2001) Ultrasonic depolymerization of an exopolysaccharide produced by a bacterium isolated from a deep-sea hydrothermal vent polychaete annelid. Ultrason Sonochem 14(2): 107-112.

Rigouin C, Delbarre-Ladrat C, Ratiskol J, Sinquin C, Colliec-Jouault S, Dion M (2012) Screening of enzymatic activities for the depolymerization of the marine bacteria exopolysaccharide HE800. Appl Microbiol Biotechnol 96(1): 143-151.

Rougeaux H, Guezennec J, Carlson RW, Kervarec N, Pichon R, Talaga, P (1999) Structural determination of the exopolysaccharide of Pseudoalteromonas strain HYD 721 isolated from a deep-sea hydrothermal vent. Carbohydr Res 315:273-285.

Stone BA, Svensson B, Collins ME, Rastall RA, (2008) Polysaccharide Degradation, in: Dr, B.O.F.-R.P., Dr, K.T.P., Dr, J.T.P. (Eds.), Glycoscience. Springer Berlin Heidelberg, pp. 2325-2375.

Sutherland IW (1995) Polysaccharides lyases. FEMS Microbiol Rev 16: 323-347.

Sutherland IW (1999a) Microbial polysaccharides from Gram-negative bacteria. Int Dairy J 11: 663-674.

Sutherland IW (1999b) Polysaccharases in Biofilm. Microbial Extracellar Polymeric Substances; in : Flemming HC (ed), Springer, pp 201-216.

Thibodeau A, and Takeoka A (2006) The applications and functions of new exopolysaccharide "Deepsane" from the deepest oceans. Fragr J 34(3): 61-68.

Volpi N, Maccari F (2002) Detection of submicrogram quantities of glycosaminoglycans on agarose gels by sequential staining with toluidine blue and Stains-All. Electrophor 23(24): 4060-4066.

Wolfaardt GM, Lawrence JR, Korber DR, (1999) Function of EPS, in: Wingender, D.J., Neu, D.T.R., Flemming, P.D.H.-C. (Eds.), Microbial Extracellular Polymeric Substances. Springer Berlin Heidelberg, pp. 171-200.

Zanchetta P, Lagarde N, Guezennec J (2003a) A new bone healing material: a hyaluronic acid like bacterial exopolysaccharide. Calc Tissue Int 72(1) 74-79. 
Table 1 Percentage of sugars and proteins $(\mathrm{w} / \mathrm{w})$ determined by colorimetric methods. Percentage of sulfate $(\mathrm{w} / \mathrm{w})$ was calculated from elemental analysis. The presence of lactate and pyruvate was evaluated using high-performance anion-exchange chromatography/conductivity detection (HPAEC/CD) and checked using ${ }^{1} \mathrm{H}$ NMR. $\mathrm{X}$ : detected.

\begin{tabular}{ccccccc}
\hline & \multicolumn{3}{c}{ \% mass } & & Substituents & pH \\
& Sugars & $\begin{array}{c}\text { Protei } \\
\text { ns }\end{array}$ & Sulphate & Lactate & Pyruvate & in water \\
\hline $\begin{array}{c}\text { Native HYD657 EPS } \\
\text { Reduced HYD657 }\end{array}$ & 88 & 1 & 7.5 & $\mathrm{X}$ & $\mathrm{X}$ & 7 \\
\hline EPS & & 0.8 & $\mathrm{X}$ & $\mathrm{X}$ & $\mathrm{X}$ & 7 \\
\hline
\end{tabular}

Table 2 Molecular weight and monosaccharide ratio of the native and reduced exopolysaccharide (EPS). Molecular weight was measured by high performance size exclusion chromatography (HPSEC). Ip: polydispersity index $=\mathrm{Mw} / \mathrm{Mn}$. Osidic composition of the two EPSs was determined after acid hydrolysis, separation and quantification by High Performance Anion Exchange Chromatography with Pulsed Amperometric Detection (HPAEC/PAD). Glc: glucose, Gal: galactose, Man: mannose, Rha: rhamnose, Fuc: fucose, GlcA: glucuronic acid, GalA: galacturonic acid.

\begin{tabular}{ccccccccccc}
\hline & \multicolumn{1}{c}{ Molecular weight } & \multicolumn{1}{c}{ Molar ratio } \\
\hline & Mw (g/mol) & Ip & Glc & Gal & Man & Rha & Fuc & GlcA & GalA \\
\hline Native HYD657 EPS & $1.510^{6}$ & 1.2 & 1 & 1.9 & 0.4 & 0.6 & 0.2 & 1.2 & 2.8 \\
\hline Reduced HYD657 EPS & $9.8 .10^{5}$ & 1.1 & 1 & 1.9 & 0.5 & 0.7 & 0.3 & 1.3 & 2.7 \\
\hline
\end{tabular}


Table 3 Amount of paranitrophenol (PNP) released after incubation of PNP-oside substrates with proteins extracts. $100 \mu \mathrm{L}$ of a $500 \mu \mathrm{moL} / \mathrm{ml} \mathrm{PNP-oside} \mathrm{substrate} \mathrm{solution} \mathrm{was} \mathrm{incubated}$ with $100 \mu \mathrm{L}(380 \mu \mathrm{g} / \mathrm{ml})$ of protein extract at $30^{\circ} \mathrm{C}$ for $10 \mathrm{~h}$. The amount of PNPs was calculated by measuring the optical density at $410 \mathrm{~nm}$. nd: not detected.

\begin{tabular}{cc}
\hline Paranitrophenyl-oside & Paranitrophenol $(\mu \mathrm{mol} / \mathrm{mL})$ \\
\hline$\alpha-D-M a n$ & nd \\
\hline$\beta-D-M a n$ & nd \\
\hline$\alpha-D-G a l$ & nd \\
\hline$\beta-D-G a l$ & $238.7_{+/-8}$ \\
\hline$\alpha-D-G l c$ & $23.3_{+/-4}$ \\
\hline$\beta-D-G l c$ & $265_{+/-11}$ \\
\hline$\alpha-L-F u c$ & nd \\
\hline$\beta-L-F u c$ & $188.2_{+/-5}$ \\
\hline$\alpha-L-R h a m$ & nd \\
\hline$\beta-D-G l c A$ & $11_{+/-1}$ \\
\hline$\alpha-D-X y l$ & nd \\
\hline$\beta-D-X y l$ & nd \\
\hline$\beta-D-G l c N a c$ & nd
\end{tabular}

Table 4 Osidic composition of the initial reduced exopolysaccharide (EPSr), the main peak of the hydrolyzed EPSr and the resistant fraction. Osidic compositions were determined using High Performance Anion Exchange Chromatography with Pulsed Amperometric Detection (HPAEC/PAD). Glc: glucose, Gal: galactose, Man: mannose, Rha: rhamnose, Fuc: fucose, GlcA: glucuronic acid, GalA: galacturonic acid.

\begin{tabular}{cccccccc}
\hline Osidic composition (molar ratio) & Glc & Gal & Man & Rha & Fuc & GlcA & GalA \\
\hline Reduced HYD 657 EPS & $1_{ \pm 0.09}$ & $1.9_{ \pm 0.17}$ & $0.5_{ \pm 0.04}$ & $0.7_{ \pm 0.07}$ & $0.3_{ \pm 0.04}$ & $1.3_{ \pm 0.18}$ & $2.7_{ \pm 0.33}$ \\
\hline Hydrolyzed HYD 657 EPS & $1_{ \pm 0.3}$ & $0.15_{ \pm 0.2}$ & $0.1_{ \pm 0.06}$ & $0.3_{ \pm 0.11}$ & 0 & $1.2_{ \pm 0.42}$ & $2.5_{ \pm 1}$ \\
\hline Resistant HYD 657 fraction & $0.6_{ \pm 0.06}$ & $1.1_{ \pm 0.1}$ & $0.3_{ \pm 0.05}$ & $0.4_{ \pm 0.03}$ & $0.12_{ \pm 0.03}$ & $1.3_{ \pm 0.24}$ & $2.6_{ \pm 0.47}$ \\
\hline
\end{tabular}




\section{Figures}

Fig.1 Electrophoretic migration on a 1\% agarose gel of the native exopolysaccharide (EPS) and the reduced EPS (EPSr) upon incubation with the protein extracts from crude lysate (LD), lysate (L), or unwashed-ell debris (D). All the protein extracts were produced from the culture of the Alteromonas strain in Zobell medium containing glucose (ZG). EPS and extracts were analyzed at the incubation time of $T=0$ and at 5 days (T5). Patterns of single EPS (EPS) and isolated extracts (LD, L, D) incubated with buffer only were also analyzed. The arrow indicates the direction of migration. HMW: high molecular weight; LMW: low molecular weight

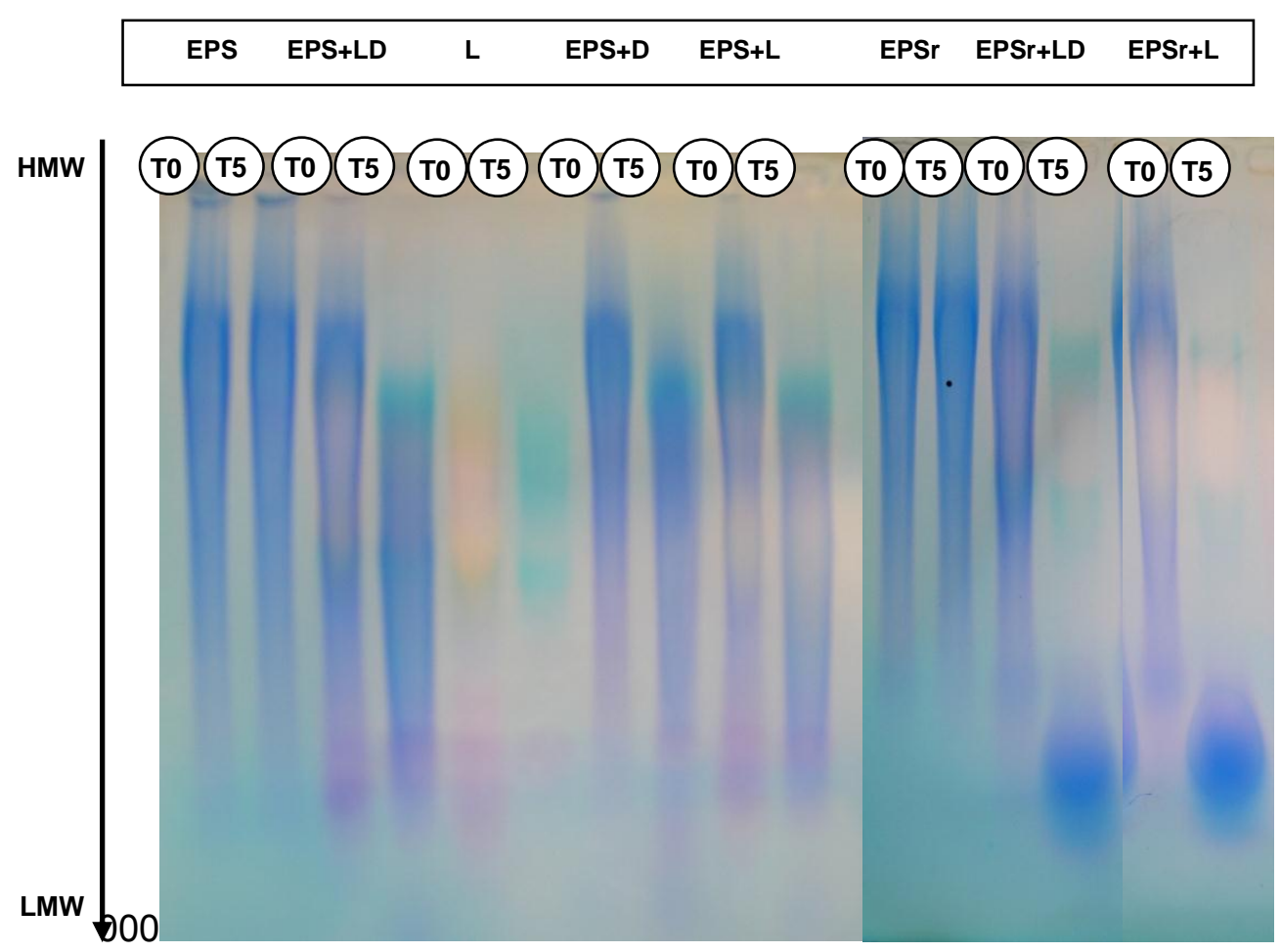


Fig. 2 Electrophoretic migration on a 1\% agarose gel of the reduced exopolysaccharide (EPSr) upon incubation with the protein extracts from lysate $(L)$ produced from culture of the Alteromonas strain in the Zobell medium containing glucose (ZG). Incubation times, indicated in the circles, vary from $0.2 \mathrm{~h}$ to $33 \mathrm{~h}$. The protein extract $(\mathrm{L})$ and the $\mathrm{EPSr}$ were incubated alone in buffer to determine if there was any potential auto-hydrolysis. The arrow indicates the direction of migration.

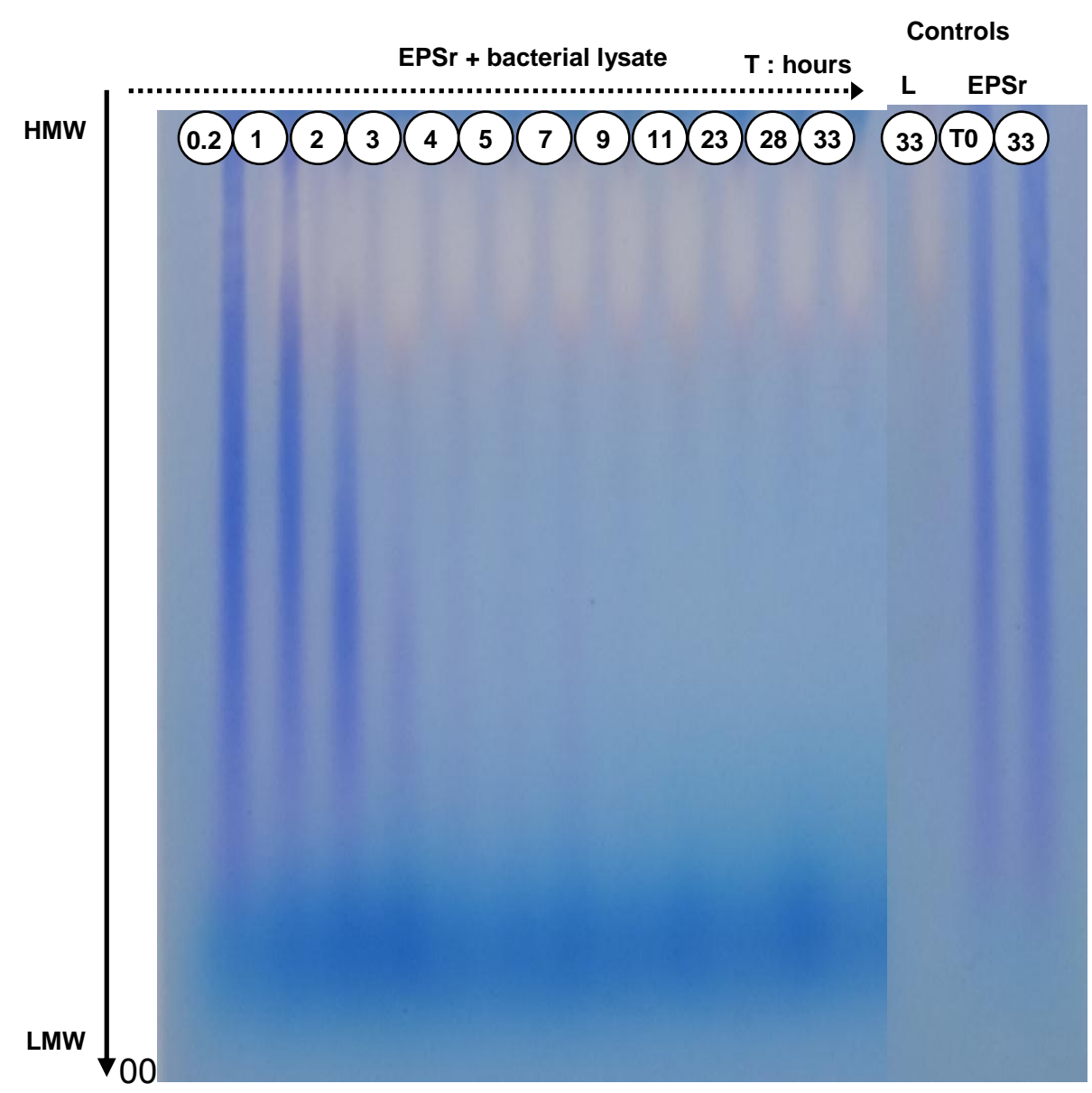


Fig. 3 Decrease in exopolysaccharide (EPS) molecular weight as a function of incubation time in hours. The molecular weight was measured by size exclusion chromatography on a Superdex 200 column, with $0.1 \mathrm{M}$ ammonium acetate buffer as the eluent at a flow rate of $0.5 \mathrm{ml} \cdot \mathrm{min}^{-1}$. Reduced EPS (EPSr) was incubated with proteins from the lysate (L) obtained from the Zobell + glucose medium. T0: initial time, T1: 1h; T2: 2h; T4: 4h; T7: 7h

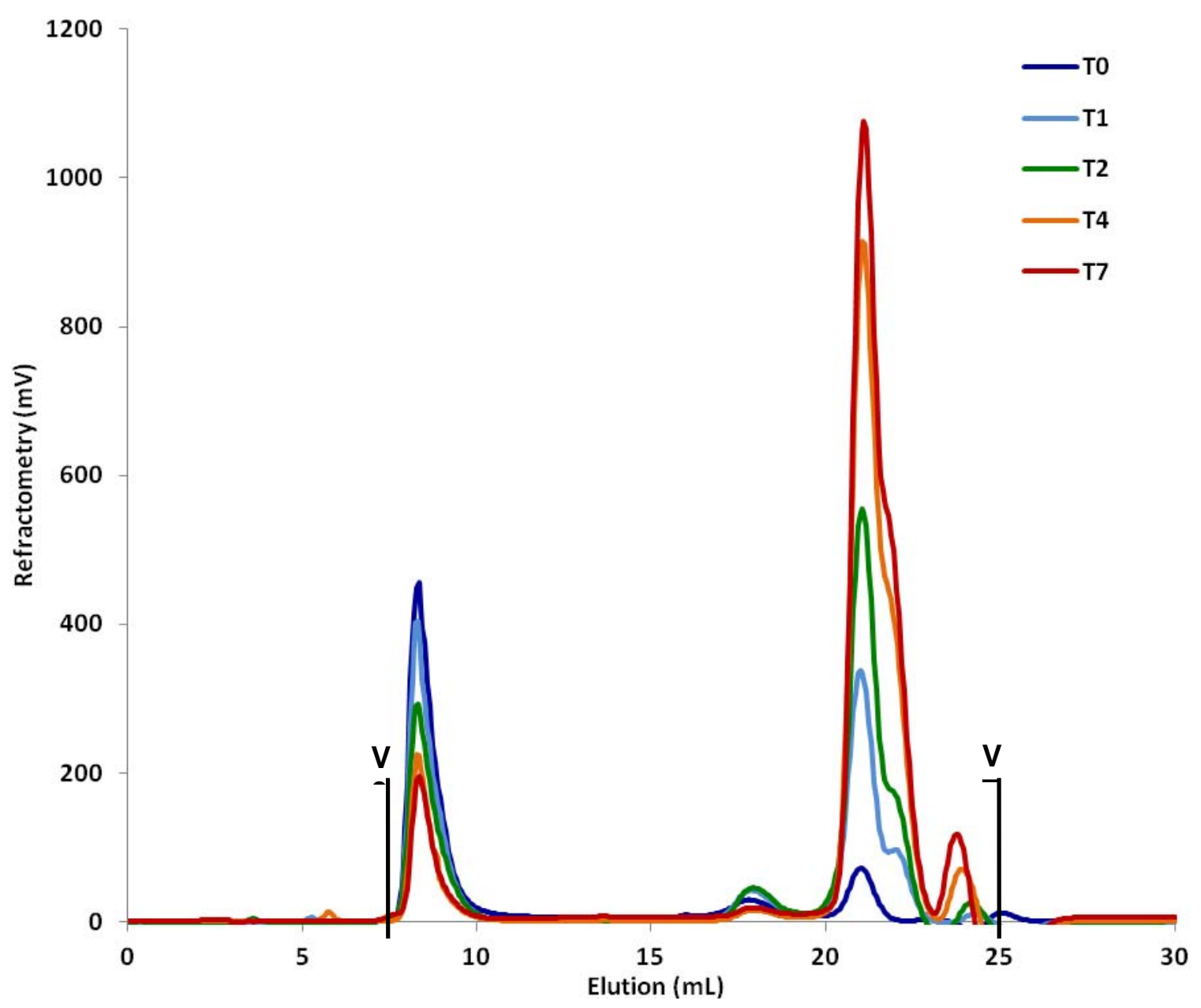


Fig. 4 Amount of reducing sugars detected assessed using the ferricyanide assay. The lysate $(\mathrm{L})$ produced from culture in Zobell + glucose medium was incubated with the reduced exopolysaccharide (EPSr) at $30^{\circ} \mathrm{C}$ in $10 \mathrm{mM}$ Tris $\mathrm{HCl}, 0.1 \mathrm{M} \mathrm{NaCl}, \mathrm{pH}$, for $33 \mathrm{~h}$. The optical density of the samples was read at $420 \mathrm{~nm}$.

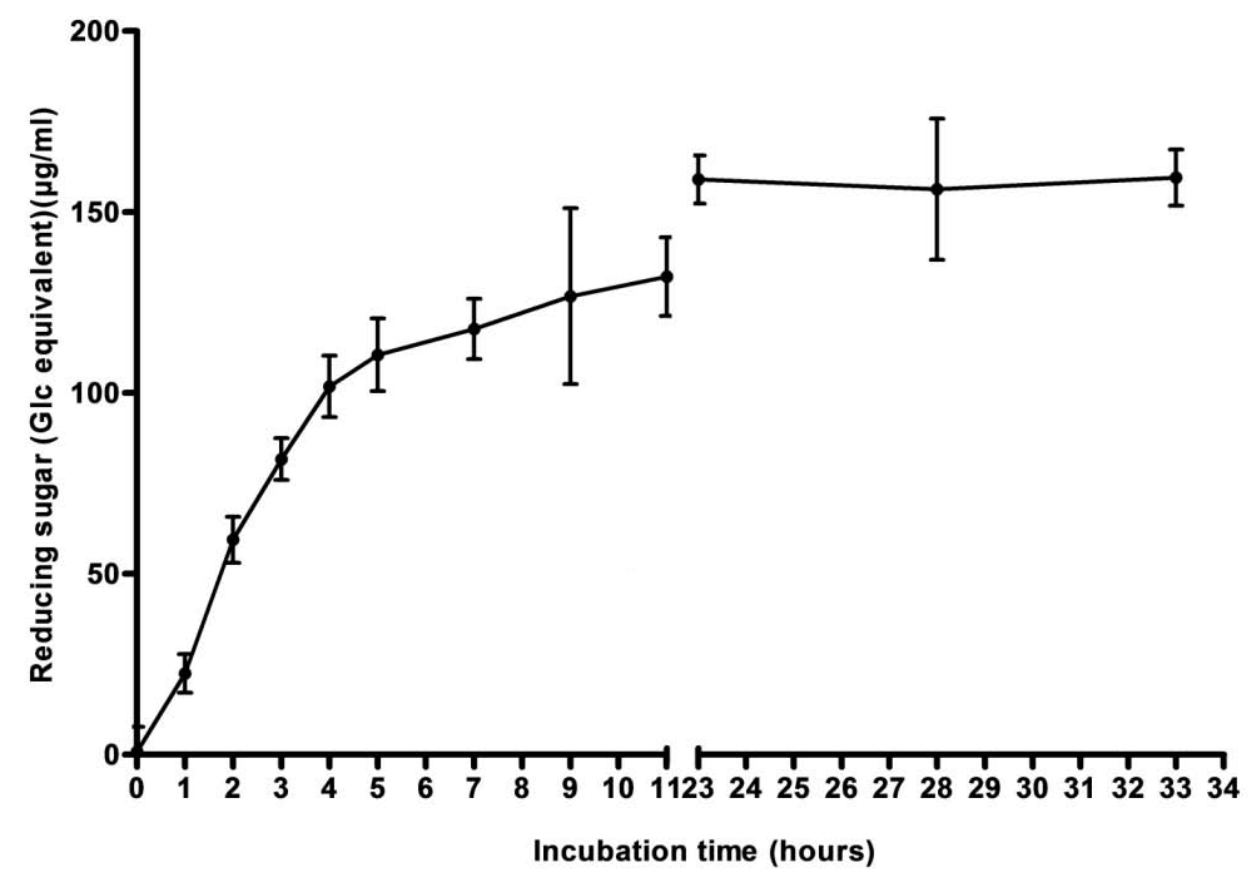


Fig. 5 Amount of paranitrophenol released after incubation of paranitrophenyl (PNP)-oside substrates with protein lysate. Five hundred micromoles of paranitrophenyl (PNP)-oside substrates were incubated with $100 \mu \mathrm{L}$ of protein lysate at $30^{\circ} \mathrm{C}$ for $10 \mathrm{~h}$. The amount of PNPs was calculated by measuring the optical density at $410 \mathrm{~nm}$. aglc paranitrophenyl- $\alpha-\mathrm{d}-$ glucopyranoside, $\beta$ glc paranitrophenyl- $\beta$-d-glucopyranoside, $\beta$ gal paranitrophenyl- $\beta-\alpha-$ galactopyranoside, $\beta$ fuc paranitrophenyl- $\beta$ - $d$-fucopyranoside, $\alpha \mathrm{GlcA}$ paranitrophenyl- $\alpha-\alpha-$ glucuropyranoside

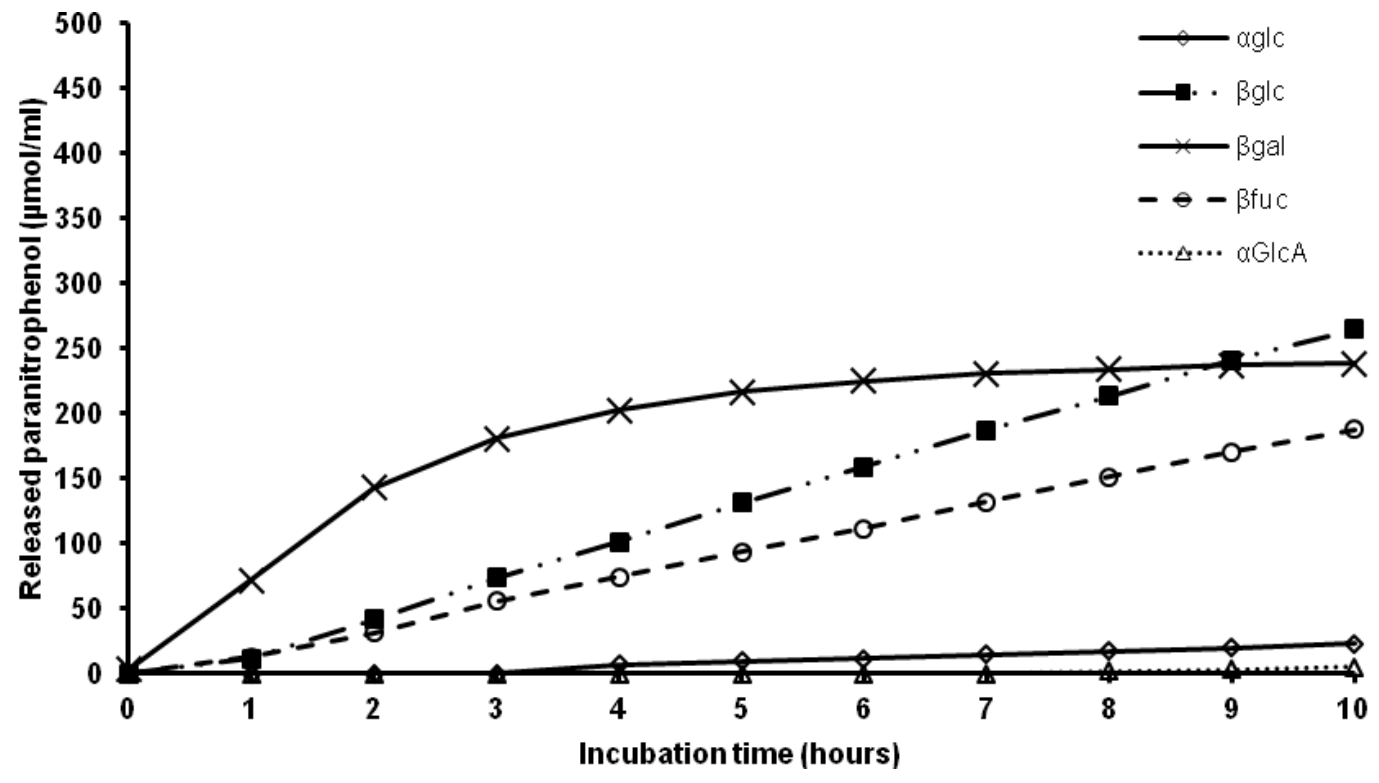

